\title{
Aplikasi Pembelajaran Multimedia Interaktif Mata Pelajaran IPA Mengenai Sistem Pencernaan Manusia Untuk Siswa SMP Kelas VII
}

\author{
R P Dhaniawaty ${ }^{1}$, A L Suci ${ }^{2}$, B Hardiyana ${ }^{3}$ \\ Program Studi Sistem Informasi, Universitas Komputer Indonesia \\ Jl. Dipatiukur No. 112-116, Bandung, 40132, Indonesia \\ ranipuspita@email.unikom.ac.id*1, angellie1131@mahasiswa.unikom.ac.id², \\ bella.hardiyana@email.unikom.ac.id ${ }^{3}$ \\ diterima: 09 September 2021 \\ direvisi: 10 Oktober 2021 \\ dipublikasi: 25 Oktober 2021
}

\begin{abstract}
Abstrak
Komponen utama yang perlu diperhatikan oleh pihak sekolah menengah pertama untuk meningkatkan kualitas proses belajar yaitu pengajar, materi pelajaran dan media pembelajaran. Media pembelajaran yang dapat membantu proses belajar mengajar mata pelajaran IPA mengenai sistem pencernaan manusia dengan menggunakan teks, video, animasi, dan game adalah multimedia pembelajaran interaktif. Proses pembelajaran IPA pada SMP PGRI Limbangan masih menggunakan cara konvensional, sehingga siswa mengalami kesulitan dalam memahami proses perubahan makanan menjadi gizi bagi tubuh manusia. Tujuan dari penelitian ini adalah membuat aplikasi yang dapat membantu guru dalam menyampaikan materi pelajaran dengan menggunakan multimedia dan membantu meningkatkan motivasi siswa. Metode pengembangan sistem yang digunakan pada penelitian ini yaitu metode ADDIE (Analysis, Design, Development, Implementation dan Evaluation). Hasil dari penelitian ini adalah sebuah aplikasi pembelajaran multimedia interaktif mata pelajaran IPA mengenai proses sistem pencernaan manusia.
\end{abstract}

Kata kunci: Aplikasi Pembelajaran; Multimedia Interaktif; IPA; Sistem Pencernaan Manusia; Siswa SMP

\begin{abstract}
The main components that need to be considered by the junior high school to improve the quality of the learning process are teachers, subject matter, and interactive learning media Learning media that can help the teaching and learning process of science subjects regarding the human digestive system by using text, videos, animations, and games is interactive multimedia learning. The science learning process at SMP PGRI Limbangan still uses conventional methods, so students have difficulty understanding the process of changing food into nutrition for the human body. The purpose of this research is to create applications that can help teachers to deliver subject matter using multimedia and help increase student motivation. The system development method used in this research is the ADDIE method (Analysis, Design, Development, Implementation, and Evaluation). The result of this research is an interactive multimedia learning application for science subjects regarding the process of the human digestive system.
\end{abstract}

Keywords: Learning Application; Interactive Multimedia; Science; Human Digestive System; Junior High School Student

\section{Pendahuluan}

Teknologi informasi merupakan sebuah media yang dapat membantu proses pembelajaran agar lebih mudah dijangkau dimana saja dan kapan saja [1,2]. Pemanfaatan teknologi dalam proses belajar mengajar dapat membantu siswa untuk lebih memahami 
materi pelajaran yang diberikan dan membantu guru dalam menyampaikan materi pelajaran secara visual. Aplikasi pembelajaran multimedia interaktif merupakan salah satu media pendukung dalam proses belajar mengajar yang menggabungkan semua media dari mulai text, gambar, video, animasi, audio dan games. Ilmu Pengetahuan Alam (IPA) merupakan salah satu mata pelajaran yang membutuhkan dukungan media pembelajaran interaktif, karena mata pelajaran ini sulit dijelaskan hanya dengan menggunakan text dan gambar saja [3]. Pada penelitian mengenai pengaruh media pembelajaran interaktif terhadap hasil belajar siswa menyatakan bahwa $23,89 \%$ siswa mengalami peningkatan terhadap hasil belajar IPA, $39,44 \%$ menyatakan multimedia interaktif membantu proses belajar dan $41,77 \%$ menyatakan bahwa mata pelajaran biologi menjadi lebih menarik untuk dipelajari dengan adanya media pembelajaran interaktif [4]. Sedangkan pada penelitian lain mengatakan bahwa siswa dan guru membutuhkan aplikasi pembelajaran multimedia interaktif pada pelajaran IPA untuk membantu dalam memberikan visualisasi terhadap beberapa proses yang tidak dapat dipraktekkan secara langsung pada saat proses pembelajaran berlangsung $[5,6]$. Sistem pencernaan manusia merupakan salah satu materi yang terdapat pada mata pelajaran IPA. Materi ini membutuhkan adanya visualisasi mengenai sistem kerja organ pencernaan manusia dalam mengubah makanan atau minuman menjadi gizi bagi tubuh [7].

Pembelajaran IPA pada sekolah menengah pertama menggunakan buku yang berikan oleh Pemerintah dalam rangka implementasi kurikulum 2013. Didalam buku IPA kurikulum 2013 ini terdapat beberapa materi dari bidang ilmu fisika, kimia, biologi, ilmu bumi dan antariksa [8]. Fokus utama didalam penelitian ini adalah bidang ilmu biologi dengan materi mengenai sistem pencernaan manusia untuk siswa SMP PGRI Limbangan kelas VII. Proses belajar mengajar yang dilakukan pada materi sistem pencernaan manusia ini dijelaskan secara bertahap dari mulai penjelasan materi dan ujian/quiz. Tahapan pertama yang dilakukan oleh guru yaitu memberikan pejelasan mengenai materi sistem pencernaan manusia dengan menggunakan media buku dan siswa menyimak pemaparan yang diberikan oleh guru. Setelah itu, tahap kedua guru menjelaskan fungsi organ pencernaan manusia dan menunjukkan alur proses pencernaan manusia dari tahap awal sampai akhir dengan menggunakan media patung organ tubuh manusia. Sedangkan pada tahap ketiga guru memberikan ujian/quiz kepada siswa dalam bentuk essay, pemberian ujian/quiz ini yaitu untuk mengetahui tingkat pemahaman siswa terhadap materi sistem pencernaan manusia. Setelah siswa mengerjakan ujian/quiz, hasil ujian dikumpulkan untuk dinilai dan dibagikan kembali kepada siswa untuk proses evaluasi pembelajaran. Berdasarkan hasil analisis, observasi dan wawancara yang dilakukan di SMP PGRI Limbangan, terdapat beberapa masalah terkait dengan proses belajar mengajar. Pada proses pembelajaran tersebut guru mengalami kesulitan dalam memaparkan alur proses dari organ pencernaan manusia dan kesulitan dalam memperagakan mekanisme perubahan makanan yang masuk kedalam sistem pencernaan manusia menjadi energi atau gizi bagi tubuh. Dikarenakan keterbatasan media pengajaran yang hanya dalam bentuk buku dan patung organ tubuh manusia, siswa kesulitan dalam melakukan visualisasi terhadap perubahan makanan/minuman yang masuk kedalam tubuh. Agar proses belajar mengajar menjadi lebih menarik dan interaktif, maka dibutuhkan sebuah aplikasi pembelajaran multimedia interaktif yang dapat membantu guru dalam memberikan penjelasan dan visualisasi terhadap materi yang diberikan.

Tujuan dari penelitian ini yaitu membuat aplikasi pembelajaran multimedia interaktif pada bidang IPA mengenai materi sistem pencernaan manusia untuk siswa menengah pertama kelas VII di SMP PGRI Limbangan. Aplikasi pembelajaran multimedia interaktif ini dapat membantu guru dalam menyampaikan materi mengenai mekanisme perubahan makanan yang masuk kedalam sistem pencernaan manusia menjadi energi atau gizi bagi tubuh dengan dilakukan visualisasi menggunakan animasi, sehingga akan terlihat bagaimana 
cara kerja setiap bagian organ pencernaan ketika makanan/minuman masuk kedalam tubuh. Selain itu media pembelajaran interakif ini memberikan pemaparan materi dalam bentuk text, animasi, video, audio dan games, sehingga dapat meningkatkan motivasi belajar siswa dan siswa dapat lebih memahami proses yang terjadi didalam sistem pencernaan manusia [9]. Pada ujian/quiz didalam media pembelajaran interaktif ini disajikan dalam bentuk latihan soal pilihan ganda. Penilaian dan evaluasi akan langsung muncul jika latihan soal sudah selesai dikerjakan. Selain itu uji kompetensi juga disajikan dalam bentuk games interaktif sederhana terkait dengan materi sistem pencernaan manusia.

\section{Kajian Pustaka}

Pembelajaran adalah sebuah proses interaksi antara peserta didik dan pendidik pada sebuah lingkungan belajar untuk saling bertukar informasi. Proses pembelajaran membutuhkan sebuah media sebagai perantara dalam menyampaikan materi pembelajaran. Media pembelajaran merupakan sebuah sarana yang dapat membantu menyampaikan proses pembelajaran menjadi lebih efektif, meningkatkan kualitas proses belajar mengajar dan meningkatkan motivasi belajar [10,11]. Dengan adanya perkembangan teknologi, media pembelajaran saat ini sudah mulai dikemas kedalam bentuk yang lebih menarik dan kreatif [12]. Media pembelajaran dengan dukungan teknologi disajikan dalam bentuk visual yang menarik dan interaktif dengan adanya video, audio, gambar didalam materi penjelasannya.

Multimedia merupakan sebuah kombinasi teks, suara, gambar, animasi dan video yang disampaikan dengan menggunakan komputer dalam bentuk digital interaktif [13]. Terdapat beberapa jenis multimedia, yaitu multimedia interaktif, multimedia hiperaktif dan multimedia linear. Multimedia Interaktif adalah sebuah pemanfaatan teknologi yang menggabungkan beberapa media menjadi satu kedalam sebuah tools untuk memudahkan pengguna melakukan navigasi, interaksi dan komunikasi didalamnya [14]. Media pembelajaran interaktif dapat digunakan di beberapa mata pelajaran, salah satunya mata pelajaran IPA. Mata pelajaran IPA atau sering disebut sains merupakan ilmu pengetahuan yang mempelajari mengenai alam semesta beserta dengan isinya. Mata pelajaran ini membutuhkan media pembelajaran multimedia interaktif untuk mendukung proses pembelajarannya, karena diperlukan adanya visualisasi dalam bentuk animasi terhadap materi yang disampaikan pendidik. Salah satu materi pelajaran IPA yang membutuhkan media pembelajaran multimedia interaktif adalah sistem pencernaan manusia. Sistem pencernaan manusia merupakan beberapa organ pencernaan yang terdapat pada manusia, beberapa organ ini saling berkaitan satu sama lain untuk memproses dan mengubah makanan atau minuman menjadi energi dan nutrisi didalam tubuh [15].

Implementasi media pembelajaran multimedia interaktif ini sudah pernah dilakukan pada beberapa penelitian terdahulu, salah satunya yaitu penelitian mengenai penggunaan aplikasi pembelajaran multimedia interaktif mata pelajaran biologi di SMA swasta salatiga yang menyimpulkan bahwa aplikasi ini sangat membantu guru dan siswa dalam proses belajar mengajar mata pelajaran IPA terutama biologi [16]. Untuk penelitian yang kedua mengenai implementasi metode MDLC pada aplikasi multimedia interaktif algoritma dan pemrograman yang dapat meningkatkan motivasi belajar mahasiswa karena materi pembelajaran dikemas dalam bentuk games [17]. Perbedaan penelitian ini dengan penelitian sebelumnya terletak pada metode pengembangan sistem yang digunakan yaitu metode ADDIE dan terdapat fitur yang disediakan pada aplikasi seperti bank soal. Fitur bank soal ini dapat diakses oleh guru untuk mengetahui pencapaian hasil belajar siswa. 


\section{Metode Penelitian}

Metode pengembangan sistem yang digunakan pada penelitian ini yaitu metode ADDIE. Metode ADDIE merupakan salah satu model yang umum digunakan dalam membuat desain pembelajaran yang efektif. Model ini merupakan singkatan dari Analysis, Design, Development, Implementation dan Evaluation [18]. Selain itu model ini dapat digunakan pada pembelajaran online, tatap muka, pengembangan produk seperti media atau bahan ajar. Berikut ini merupakan tahapan dari metode ADDIE secara lengkap pada gambar 1 dibawah ini :

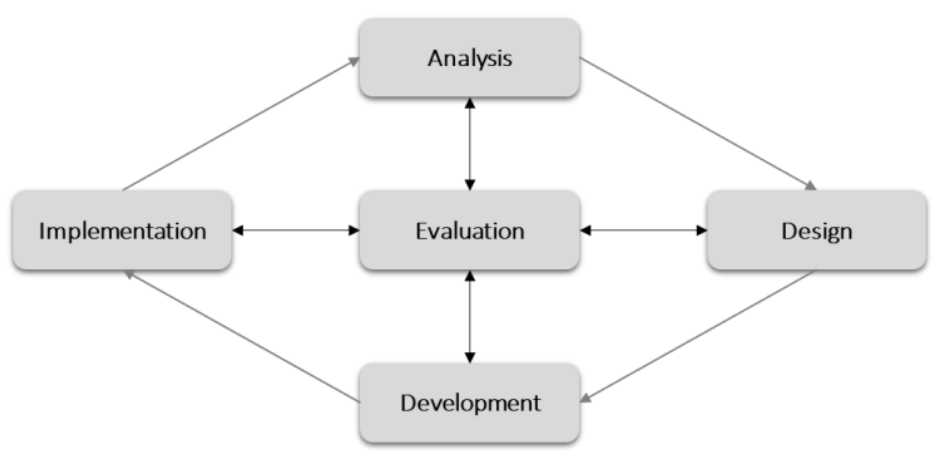

Gambar 1. Metode Pengembangan Sistem ADDIE

Tahapan pertama pada metode pengembangan sistem ADDIE adalah Analisis. Tahapan ini melakukan analisis kebutuhan materi pembelajaran (bahan ajar), analisis kurikulum yang digunakan, analisis karakteristik siswa, analisis kebutuhan perangkat lunak dan analisis kebutuhan perangkat keras. Tahapan kedua yaitu desain dengan membuat struktur menu aplikasi terlebih dahulu kemudian dilanjutkan dengan membuat storyboard aplikasi pembelajaran interaktif, penyusunan materi dan soal latihan, pembuatan background aplikasi pembelajaran, gambar dan tombol yang akan digunakan pada aplikasi. Setelah storyboard selesai masuk ke tahapan ketiga yaitu pengembangan (development), pada tahapan ini dilakukan pembuatan aplikasi pembelajaran interaktif dengan menggunakan aplikasi Adobe Flash CS6, validasi aplikasi pembelajaran yang dilakukan oleh validasi ahli multimedia dan ahli materi terkait kelayakan aplikasi pembelajaran interaktif dan revisi aplikasi pembelajaran interaktif. Selanjutnya terdapat tahapan implementasi, tahapan ini merupakan tahapan uji coba aplikasi pembelajaran interaktif. Uji coba ini dilakukan oleh siswa dan guru sebagai pengguna. Setelah dilakukan uji coba pada aplikasi pembelajaran interaktif, maka tahapan selanjutnya adalah evaluasi. Pada tahapan ini dilakukan perbaikan terhadap aplikasi pembelajaran interaktif berdasarkan hasil uji coba yang sudah dilakukan dan disesuaikan dengan kebutuhan pengguna [19].

\subsection{Tahap Analysis}

\section{Hasil dan Pembahasan}

Aplikasi pembelajaran multimedia ineraktif sistem pencernaan manusia ini ditujukan untuk siswa SMP kelas VII. Berdasarkan obsevasi dan wawancara yang telah dilakukan terhadap analisis kebutuhan untuk pengguna aplikasi pembelajaran multimedia interaktif yaitu dibutuhkan adanya visualisasi dalam bentuk animasi yang dapat menjelaskan cara kerja sistem pencernaan manusia, mekanisme perubahan makanan menjadi energi/gizi bagi tubuh manusia, soal pilihan ganda dan beberapa essay yang dikemas kedalam bentuk games. Bahan ajar yang digunakan dalam penelitian ini adalah buku mata pelajaran IPA kurikulum 2013 yang dikeluarkan oleh Kementrian Pendidikan dan Kebudayaan Republik Indonesia pada tahun 2017, kurikulum 2013 ini digunakan oleh seluruh SMP di Indonesia. 


\subsection{Tahap Design}

Terdapat beberapa proses yang dilakukan pada tahap desain ini yaitu membuat struktur menu aplikasi yang berfungsi untuk memberikan informasi terkait menu yang disediakan pada aplikasi. Pada menu aplikasi media pembelajaran multimedia interaktif sistem pencernaan manusia terdapat 3 menu yang saling berkaitan yaitu menu utama, materi pembelajaran, latihan dan games seperti pada gambar 2 dibawah ini.

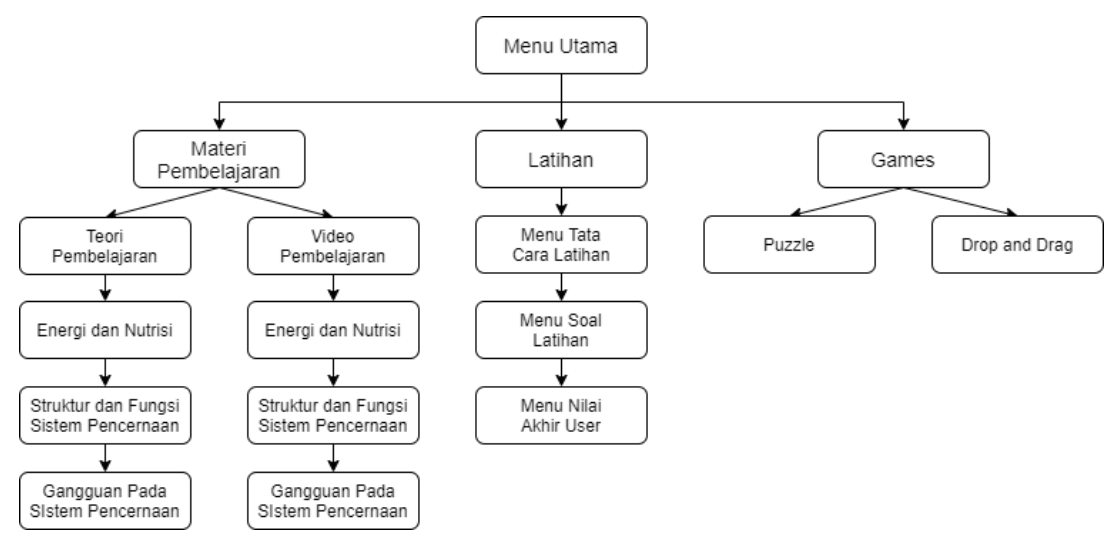

Gambar 2. Struktur Menu Aplikasi

Setelah membuat struktur menu aplikasi, langkah selanjutnya yang dilakukan yaitu membuat storyboard aplikasi pembelajaran multimedia interaktif sistem pencernaan manusia. Storyboard merupakan sebuah gambaran serta penjelasan terkait media pembelajaran interaktif yang akan dijadikan paduan oleh programmer/desain grafis dalam membangun aplikasi. Perancangan storyboard aplikasi pembelajaran multimedia interaktif sistem pencernaan manusia dimulai dengan menu utama yang terdiri dari materi pembelajaran, latihan soal dan games. Pada menu materi pembelajaran menampilkan beberapa bab pembahasan mengenai energi, nutrisi, struktur, fungsi dan gangguan pada sistem pencernaan manusia yang disajikan dalam bentuk text, animasi, audio dan video sesuai dengan isi materi pada buku mata pelajaran IPA untuk siswa SMP kelas VII. Menu latihan soal menampilkan 20 soal pilihan ganda mengenai sistem pencernaan manusia, dalam proses menjawab soal pengguna akan melihat tampilan salah, benar dan hasil akhir nilai yang didapatkan. Sedangkan pada menu games menampilkan beberapa permainan yang disajikan dalam bentuk gambar animasi 2D.

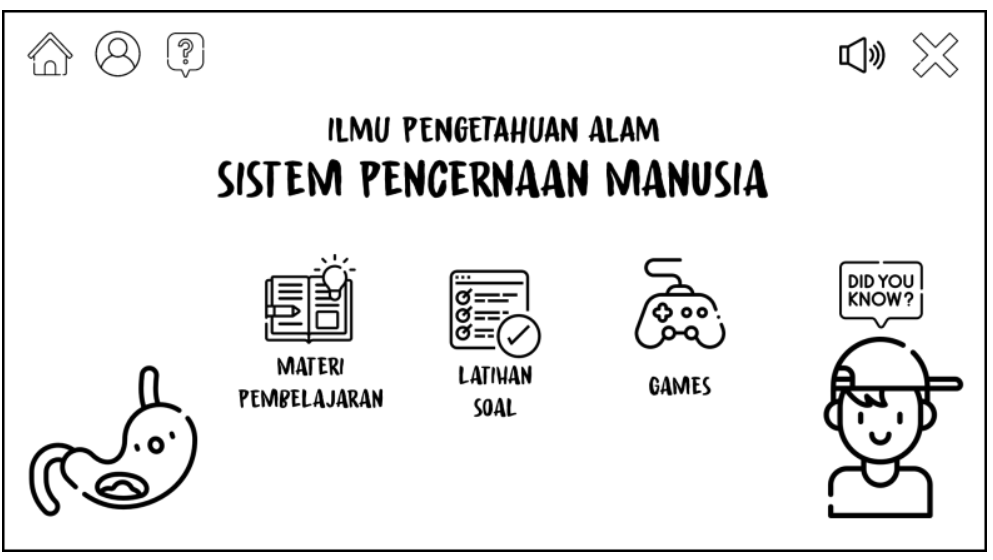

Gambar 3. Storyboard Aplikasi Pembelajaran Multimedia Interaktif

"Sistem Pencernaan Manusia" 


\subsection{Tahap Development}

Pada tahapan yang ketiga yaitu tahap development dilakukan pembuatan aplikasi pembelajaran berbasis desktop dengan menggunakan Adobe Flash CS6. Pembuatan aplikasi pembelajaran sistem pencernaan manusia ini mengikuti alur storyboard yang sudah dibuat. Pada gambar 4 dibawah ini merupakan user interface aplikasi pembelajaran multimedia interaktif pada materi pembahasan mengenai struktur dan fungsi sistem pencernaan manusia. User interface materi pada gambar sebelah kiri menggunakan media audio yang menjelaskan mengenai sub materi struktur dan fungsi sistem pencernaan manusia dengan didukung adanya animasi bergerak proses perubahan makanan atau minuman yang akan dicerna didalam tubuh. Sedangkan untuk user interface pada gambar sebelah kanan, jika kursor diletakkan dibagian sistem pencernaan manusia maka akan muncul audio dan informasi lengkap mengenai organ tubuh manusia yang dipilih.
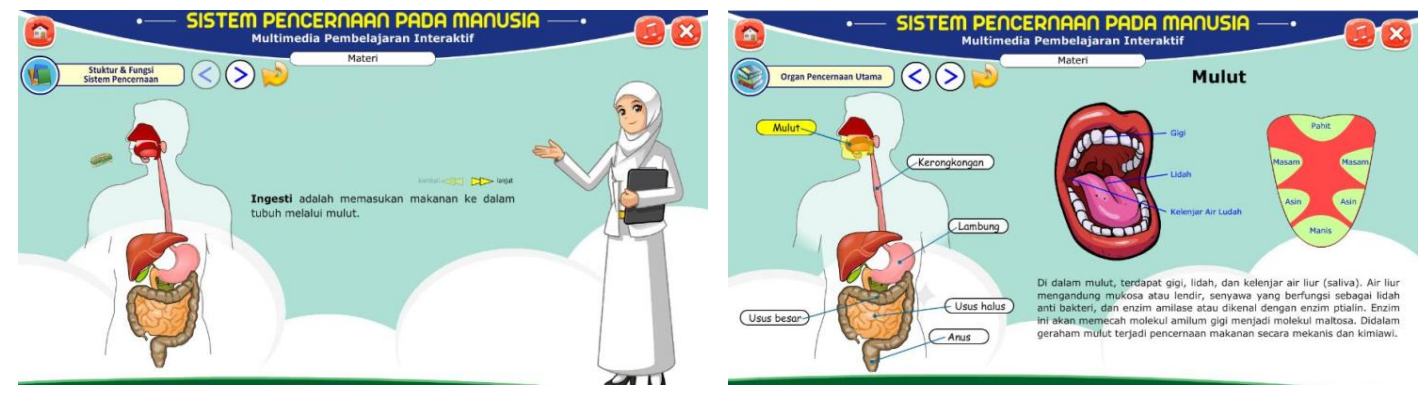

Gambar 4. Tampilan User Interface Materi

Latihan soal pada aplikasi pembelajaran ini berfungsi untuk mengetahui pemahaman pengguna terhadap materi yang sudah diberikan sebelumnya. Gambar 5 merupakan tampilan latihan soal yang dibuat pada aplikasi pembelajaran, soal yang disajikan dalam bentuk pilihan ganda yang disertai dengan gambar dan disesuaikan dengan sub materi yang sudah dipelajari sebelumnya. Sebelum mengerjakan latihan soal pengguna dapat membaca terlebih dahulu mengenai petunjuk pengerjaan soal. Petunjuk pengerjaan soal berisi mengenai informasi jumlah soal yang akan dikerjakan, poin jawaban benar dan salah ketika mengerjakan soal dan minimal nilai yang dinyatakan lulus. Saat pengguna mengerjakan soal, jika jawaban benar maka akan muncul tampilan "jawaban kamu benar", tetapi jika jawaban salah maka akan muncul tampilan "jawaban kamu kurang tepat nih" yang disertai dengan jawaban benar dan penjelasannya. Setelah pengguna mengerjakan 20 soal yang disajikan dalam latihan soal, maka akan muncul tampilan skor nilai, pernyataan lulus atau belum lulus, jumlah jawaban salah dan benarnya.
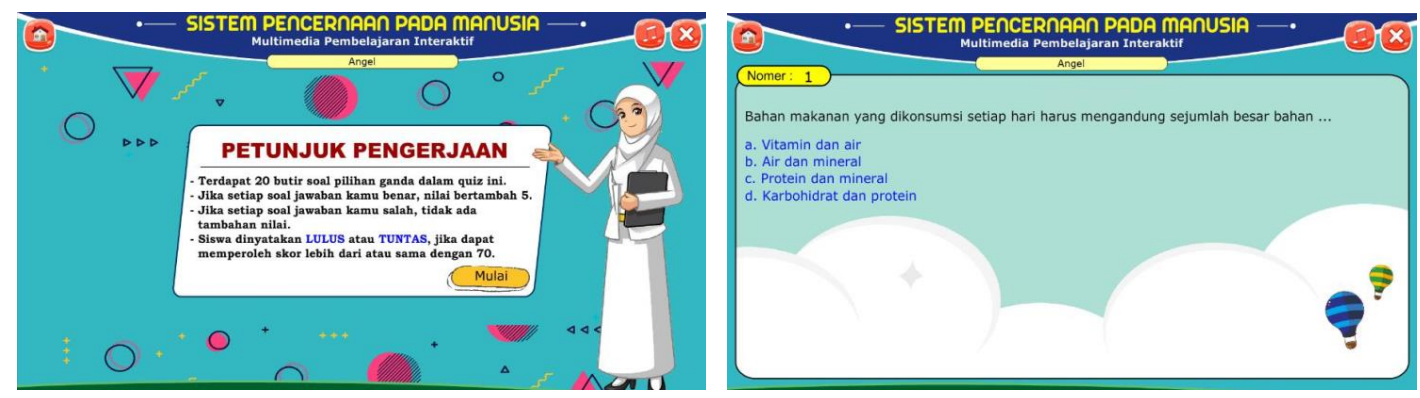

Gambar 5. Tampilan User Interface Latihan Soal

Games yang terdapat pada aplikasi pembelajaran ini berfungsi untuk menarik minat belajar pengguna untuk belajar IPA mengenai sistem pencernaan manusia sambil bermain. 
Terdapat dua jenis games yaitu puzzle dan drag \& drop yang dapat dilihat pada gambar 6 , pada games jenis puzzle, pengguna diarahkan untuk mengingat letak dari organ sistem pencernaan manusia. Sedangkan untuk games jenis drag \& drop, pengguna diarahkan untuk mencocokkan objek organ sistem pencernaan manusia dengan nama organnya.
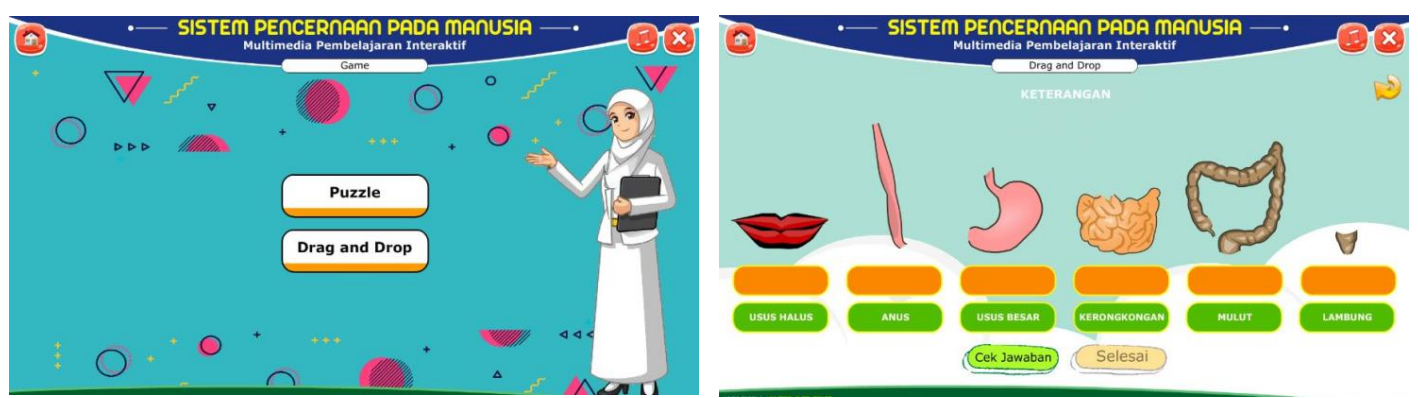

Gambar 6. Tampilan User Interface Games

Langkah selanjutnya adalah melakukan validasi terhadap aplikasi yang sudah dibuat dengan menggunakan kuisioner yang diberikan kepada responden yang terdiri dari 3 ahli multimedia dan 2 ahli materi. Untuk mengetahui persentase dari responden, digunakan skala likert dengan rumus 1 sebagai berikut:

$P=\frac{f}{N} \times 100 \%$

Keterangan :

$\mathrm{P}=$ Persentase $(\%)$ yang dicari,

$\mathrm{f}=$ Jumlah responden yang memilih alternatif jawaban

$\mathrm{N}=$ Jumlah keseluruhan responden

Untuk alternatif jawaban responden didalam kuisioner, sebagai berikut :

$1=$ Sangat Tidak Puas

$2=$ Tidak Puas

$3=$ Cukup

$4=$ Puas

$5=$ Sangat Puas

Berikut ini merupakan hasil persentase penilaian yang dilakukan ahli multimedia dan materi pada beberapa aspek tampilan, pemrograman, isi dan pembelajaran dari aplikasi pembelajaran multimedia interaktif sistem pencernaan manusia :

Tabel 1. Hasil Penilaian Validasi Ahli Multimedia

\begin{tabular}{|c|c|l|c|}
\hline No & Aspek & \multicolumn{1}{|c|}{ Indikator } & Persentase \\
\hline 1 & \multirow{2}{*}{ Tampilan } & $\begin{array}{l}\text { a. Pemilihan layout yang tepat dan menarik } \\
\text { b. Pemilihan font yang tepat } \\
\text { c. Kualitas gambar, animasi dan video yang baik } \\
\text { d. Kesesuaian animasi dengan materi } \\
\text { e. Pemilihan audio, video dan materi yang tepat } \\
\text { f. Kesesuaian tampilan dengan isi }\end{array}$ & $81 \%$ \\
\hline 2 & $\begin{array}{l}\text { a. Sesuai dengan kebutuhan pengguna } \\
\text { b. Menyediakan informasi penggunaan aplikasi } \\
\text { c. Menyajikan hasil nilai atau reward } \\
\text { d. Penggunaan navigasi (tombol) yang tepat }\end{array}$ & $86 \%$ \\
\hline \multicolumn{1}{|c|}{ Total } & $83,5 \%$ \\
\hline
\end{tabular}


Tabel 2. Hasil Penilaian Validasi Ahli Materi

\begin{tabular}{|c|c|l|c|}
\hline No & Aspek & \multicolumn{1}{|c|}{ Indikator } & Persentase \\
1 & Isi & $\begin{array}{l}\text { a. Kurikulum yang digunakan sesuai } \\
\text { b. Kesesuaian materi dengan ruang lingkup IPA } \\
\text { c. Kesesuaian media dengan karakteristik siswa } \\
\text { d. Kesesuaian cara penyampaian materi }\end{array}$ & $80 \%$ \\
\hline 2 & $\begin{array}{l}\text { a. Penyajian materi berurutan } \\
\text { b. Kesesuaian tujuan dan materi pembelajaran } \\
\text { Pembelajaran }\end{array}$ & $\begin{array}{l}\text { fenyajian materi menarik } \\
\text { d. Kesesuaian bahasa dengan sasaran pengguna } \\
\text { e. Kesesuaian latihan soal } \\
\text { f. Kualitas umpan balik }\end{array}$ & $83 \%$ \\
\hline \multicolumn{1}{|c|}{ Total } & $81,5 \%$ \\
\hline
\end{tabular}

Tabel 3. Kesesuaian Multimedia dan Materi Aplikasi Pembelajaran

\begin{tabular}{|c|c|c|}
\hline No & Range Nilai & Keterangan \\
\hline 1 & $90 \%-100 \%$ & Sangat Sesuai \\
\hline 2 & $80 \%-89 \%$ & Sesuai \\
\hline 3 & $60 \%-79 \%$ & Cukup Sesuai \\
\hline 4 & $40 \%-59 \%$ & Kurang Sesuai \\
\hline 5 & $0 \%-39 \%$ & Tidak Sesuai \\
\hline
\end{tabular}

Dari hasil penilaian validasi yang dilakukan oleh ahli multimedia pada tabel 1 didapatkan nilai sebesar $83,5 \%$. Ahli multimedia menyatakan bahwa aspek yang terdapat pada tampilan dan pemrograman sudah sesuai dan memenuhi kriteria untuk sebuah aplikasi pembelajaran multimedia interaktif. Sedangkan pada tabel 2, hasil penilaian validasi yang dilakukan ahli materi yaitu $81,5 \%$ menyatakan bahwa isi materi pembelajaran sudah sesuai dengan buku IPA siswa SMP kelas VII kurikulum 2013 dan penyajian materi tidak hanya dalam bentuk teks saja, tetapi sudah menggunakan media animasi, audio dan video untuk memberikan visualisasi dari materi yang diberikan. Berdasarkan tabel 3 menyatakan bahwa aplikasi pembelajaran sistem pencernaan manusia ini berada pada range nilai $80 \%$ - 89\% yang berarti aplikasi pembelajaran sudah sesuai dari aspek tampilan, pemrograman, isi materi dan pembelajaran.

\subsection{Tahap Implementation dan Evaluation}

Setelah dilakukan proses validasi oleh ahli multimedia dan ahli materi pada tahap development, maka langkah selanjutnya yaitu implementasi aplikasi media pembelajaran berbasis multimedia interaktif. Tabel 4 merupakan deskripsi kebutuhan software dan hardware dalam proses implementasi aplikasi pembelajaran multimedia interaktif ini.

Tabel 4. Kebutuhan Software dan Hardware

\begin{tabular}{|c|c|c|l|}
\hline No & Komponen & Kebutuhan & \multicolumn{1}{|c|}{ Deskripsi } \\
\hline \multirow{2}{*}{1} & Software & Sistem Operasi & $\begin{array}{l}\text { Untuk windows minimal menggunakan } \\
\text { windows 8 32 bit, disarankan menggunakan } \\
\text { windows 10 64 bit. }\end{array}$ \\
\cline { 3 - 5 } & Adobe Flash Player & $\begin{array}{l}\text { Untuk membuka aplikasi media } \\
\text { pembelajaran pada web browser. }\end{array}$ \\
\hline \multirow{2}{*}{2} & Hardware & $\begin{array}{c}\text { Minimum } \\
\text { Requirement }\end{array}$ & $\begin{array}{l}\text { Processor intel core i3, RAM 4 GB, mouse, } \\
\text { keyboard, speaker, HD kapasitas 80GB. }\end{array}$ \\
\cline { 3 - 5 } & $\begin{array}{c}\text { Recommended } \\
\text { Requirement }\end{array}$ & $\begin{array}{l}\text { Processor intel core i5, RAM 8 GB, mouse, } \\
\text { keyboard, speaker, HD kapasitas 500GB. }\end{array}$ \\
\hline
\end{tabular}


Tahap evaluasi pada aplikasi ini diberikan kepada 50 siswa dan 5 guru mata pelajaran IPA sebagai pengguna, untuk melakukan penilaian terhadap kesesuaian dengan kebutuhan proses belajar mengajar. Tahap ini bertujuan untuk mengetahui tingkat kepuasan pengguna dan kesesuaian media pembelajaran dengan materi yang diberikan pada saat proses belajar mengajar mata pelajaran IPA. Untuk mengetahui umpan balik yang diberikan pengguna, pengguna diberikan kuisioner yang berisi beberapa indikator penilaian. Setelah pengguna mengisi kuisioner, hasil pengisian tersebut akan diolah dengan menggunakan rumus skala likert. Skala likert menyediakan pernyataan yang disertai pilihan seperti (sangat tidak puas, tidak puas, cukup, puas, sangat puas) [20]. Tabel 5 merupakan tabel hasil penilaian dari 50 siswa dan 5 guru mata pelajaran IPA sebagai pengguna terhadap aplikasi pembelajaran multimedia interaktif sistem pencernaan manusia.

Tabel 5. Hasil Evaluasi Kepuasan Pengguna dan Kesesuaian Media Pembelajaran

\begin{tabular}{|c|l|c|}
\hline No & \multicolumn{1}{|c|}{ Indikator } & $\begin{array}{c}\text { Persen } \\
\text { tase }\end{array}$ \\
\hline 1 & Tampilan media pembelajaran menarik & $84 \%$ \\
\hline 2 & Media pembelajaran mudah digunakan & $78 \%$ \\
\hline 3 & Meningkatkan minat belajar & $85 \%$ \\
\hline 4 & Memiliki kejelasan dalam petunjuk penggunaan & $77 \%$ \\
\hline 5 & Materi mudah dipahami & $82 \%$ \\
\hline 6 & Materi sesuai dengan sumber buku yang digunakan & $80 \%$ \\
\hline 7 & Kejelasan soal latihan & $78 \%$ \\
\hline \multicolumn{2}{|c|}{ Total } & $80,57 \%$ \\
\hline
\end{tabular}

Tabel 6. Kepuasan Pengguna dan Kesesuaian Materi

\begin{tabular}{|c|c|c|}
\hline No & Range Nilai & Keterangan \\
\hline 1 & $90 \%-100 \%$ & Sangat Puas \\
\hline 2 & $80 \%-89 \%$ & Puas \\
\hline 3 & $60 \%-79 \%$ & Cukup \\
\hline 4 & $40 \%-59 \%$ & Tidak Puas \\
\hline 5 & $0 \%-39 \%$ & Sangat Tidak Puas \\
\hline
\end{tabular}

Dari hasil evaluasi kepuasan siswa dan guru sebagai pengguna aplikasi, maka diperoleh persentase sebesar $80,57 \%$ yang menyatakan bahwa aplikasi pembelajaran multimedia interaktif layak untuk digunakan sebagai media pendukung proses belajar mengajar pada mata pelajaran IPA materi sistem pencernaan manusia yang dapat meningkatkan minat belajar siswa. Untuk hasil evaluasi kepuasan pengguna terhadap beberapa indikator masih berada dibawah $80 \%$ dikarenakan terdapat beberapa kekurangan yang harus diperbaiki. Pada indikator mengenai penggunaan aplikasi media pembelajaran, masih terdapat pengguna yang kurang memahami penggunaan aplikasi secara mandiri. Untuk indikator kejelasan petunjuk penggunaan aplikasi hanya terdapat pada latihan soal saja, sedangkan untuk games tidak terdapat petunjuk pengerjaan tetapi hanya diberikan instruksi singkat saja. Indikator kejelasan latihan soal, terdapat beberapa pengguna yang menyarankan penggunaan warna pada text jawaban latihan soal terlalu terang sehingga text sulit terbaca. Perbaikan tersebut dilakukan agar keseluruhan indikator didalam aplikasi pembelajaran sistem pencernaan manusia dapat mencapai range lebih dari $80 \%$ yang berarti pengguna puas terhadap fitur yang disediakan didalam aplikasi ini. 


\section{Kesimpulan}

Media pembelajaran berbasis multimedia interaktif dapat membantu guru dalam menyampaikan materi sistem pencernaan manusia yang menarik dan interaktif dengan adanya visualisasi dalam bentuk video dan animasi. Selain itu media pembelajaran ini dapat meningkatkan motivasi dan kualitas belajar siswa dalam bidang ilmu pengetahuan alam (IPA), membantu siswa untuk melakukan proses belajar secara mandiri dimana saja dan kapan saja. Rata-rata kepuasan pengguna dalam menggunakan media pembelajaran ini yaitu $80,57 \%$, pengguna menyatakan bahwa media pembelajaran ini membantu dalam proses pembelajaran mengenai sistem pencernaan manusia yang disajikan dalam bentuk visualisasi gambar yang bergerak, teori dan video penjelasan secara singkat. Dengan adanya media pembelajaran berbasis multimedia interaktif ini dapat membantu guru dalam memberikan materi pembelajaran secara visual dan membantu proses belajar siswa dalam memahami materi pembelajaran mengenai sistem pencernaan manusia.

\section{Daftar Pustaka}

[1] Syamsuar, dan Reflianto, "Pendidikan dan Tantangan Pembelajaran Berbasis Teknologi Informasi di Era Revolusi Industri 4.0”, E-Tech Jurnal Ilmiah Teknologi Pendidikan, vol. 6, no. 2, 2018. Tersedia : http://ejournal.unp.ac.id/index.php/etech/article/view/101343. [Diakses : 09-Agustus-2021]

[2] R. Lapisa, I. Basri, M. Milana dan A. Arif, "Review Implementasi Teknologi Informasi dan Komunikasi Dalam Kegiatan Pembelajaran : Studi Kasus SMK di Kota Padang Panjang", Jurnal Pendidikan Teknologi Kejuruan, vol. 2, no. 4, pp. 103-109, 2019. Tersedia : http://jptk.ppj.unp.ac.id/index.php/jptk/article/view/60. [Diakses : 09Agustus-2021]

[3] J. B. Kelana, "The Effect of The Learning Media and The Ability to Think Creative of to The Ability to Science Literacy Student of Elementary School", Primaryedu : Journal of Elementary Education, vol. 2, no. 2, pp. 79-86, 2018. Tersedia : http://www.e-journal.stkipsiliwangi.ac.id/index.php/primaryedu/article/view/1008. [Diakses : 10-Agustus-2021]

[4] S. Sahronih, A. Purwanto dan M. S. Sumantri, "The Effect of Interactive Learning Media on Student Science Learning Outcomes", International Conference on Information and Education Technology, 2019. Tersedia : https://dl.acm.org/doi/abs/10.1145/3323771.3323797. [Diakses : 10-Agustus-2021]

[5] A. S. Putri, N. Aznam, "The Effectiveness of Science Learning Media Using Focusky Software on Junior High School Students Higher Order Thinking Skills", Scientiae Educatia : Jurnal Pendidikan Sains, vol. 8, no. 1, pp. 12-22, 2019. Tersedia https://www.syekhnurjati.ac.id/jurnal/index.php/sceducatia/article/view/3886.

[Diakses : 11-Agustus-2021]

[6] T. Hikmawan, N Sutarni dan A. Hufad, "The Role of Electronic Learning Media in Creativity Learning", Journal of Physics : Conference Series, vol. 1375, 2019. Tersedia : https://iopscience.iop.org/article/10.1088/1742-6596/1375/1/012030/meta. [Diakses : 11-Agustus-2021]

[7] A. Nofitasari, Lisdiana dan A. Marianti, "Development of My Biology App Learning Media Based on Android Materials of Food Digestion Systems as Student Learning Source at Senior High School", Journal of Innovative Science Education, vol. 10, no.1, pp. 70-78, 2021. Tersedia https://journal.unnes.ac.id/sju/index.php/jise/article/view/38670/16048. [Diakses : 11Agustus-2021] 
[8] A. Prajana dan Y. Astuti, "Pemanfaatan Teknologi Informasi dan Komunikasi Dalam Pembelajaran Oleh Guru SMK di Banda Aceh Dalam Upaya Implementasi Kurikulum 2013", JINOTEP, vol. 7, no. 1, pp. 33-41, 2020. Tersedia : http://journal2.um.ac.id/index.php/jinotep/article/view/12948. [Diakses : 12-Agustus2021]

[9] M. Triyanti, "Pengembangan Multimedia Interaktif Pada Materi Sistem Saraf Untuk Meningkatkan Motivasi dan Hasil Belajar Siswa SMA Kelas XI", Jurnal BIOEDUKATIKA, vol. 3, no. 2, pp. 9-14, 2015. Tersedia : http://bioedukatika.uad.ac.id/wp-content/uploads/2015/12/2.-Jurnal-BioedukatikaMerti-9-14.pdf. [Diakses : 13-Agustus-2021]

[10] T. Nurseto, "Membuat Media Pembelajaran Yang Menarik", JEP, vol. 8, no. 1, pp. 1935, 2011. Tersedia : https://journal.uny.ac.id/index.php/jep/article/view/706. [Diakses : 14-Agustus-2021]

[11] T. Tafonao, "Peranan Media Pembelajaran Dalam Meningkatkan Minat Belajar Mahasiswa", Jurnal Komunikasi Pendidikan, vol. 2, no. 2, pp. 103-114, 2018. Tersedia : http://journal.univetbantara.ac.id/index.php/komdik/article/view/113. [Diakses : 16Agustus-2021]

[12] H. H. Batubara, "Pengembangan Media Pembelajaran Matematika Berbasis Android Untuk Siswa SD/MI”, MUALLIMUNA, vol. 3, no. 1, pp. 12-27, 2017. Tersedia : https://ojs.uniska-bjm.ac.id/index.php/jurnalmuallimuna/article/view/952. [Diakses : 16-Agustus-2021]

[13] M. Rorita, S. Ulfa, A. Wedi, "Pengembangan Multimedia Interaktif Berbasis Mobile Learning Pokok Bahasan Perkembangan Teori Atom Mata Pelajaran Kimia Kelas X SMA Panjura Malang", JINOTEP, vol. 4, no.2, pp. 70-75, 2018. Tersedia : http://journal2.um.ac.id/index.php/jinotep/article/view/3765. [Diakses : 18-Agustus2021]

[14] Y. Kusmanagara, F. Marisa dan I. D. Wijaya, "Membangun Aplikasi Multimedia Interaktif Dengan Model Tutorial Sebagai Sarana Pembelajaran Bahasa Kanton", JIMP, vol. 3, no. 2, pp. 1-8, 2018. Tersedia : http://ejurnal.unmerpas.ac.id/index.php/informatika/article/view/165. [Diakses : 18Agustus-2021]

[15] I. Susilowati, R. S. Iswari dan S. Sukaesih, "Pengaruh Pembelajaran Berbasis Proyek Terhadap Hasil Belajar Siswa Materi Sistem Pencernaan Manusia", UNNES JOURNAL OF BIOLOGY EDUCATION, vol. 2, no. 1, pp. 82-90, 2013. Tersedia : https://journal.unnes.ac.id/sju/index.php/ujbe/article/view/2618. [Diakses : 18Agustus-2021]

[16] A. Ariyanto, D. F. Priyayi, L. Dewi, "Penggunaan Media Pembelajaran Biologi di Sekolah Menengah Atas (SMA) Swasta Salatiga", BIOEDUKASI, vol. 9, no. 1, pp. 113 , 2018. Tersedia http://www.fkip.ummetro.ac.id/journal/index.php/biologi/article/view/1377. [Diakses : 18-Agustus-2021]

[17] S. Alisyafiq, B. Hardiyana dan R. P. Dhaniawaty, "Implementation of the Life Cycle of Multimedia Development in Interactive Multimedia Learning Applications Algorithm and Basic Programming for Students with Special Needs Based on Android", JPKK, vol. 5, no. 2, pp. 135-143, 2021. Tersedia : http://jpkk.ppj.unp.ac.id/index.php/jpkk/article/view/594. [Diakses : 10-September2021]

[18] S. Bakhri, "Animasi Interaktif Pembelajaran Huruf dan Angka Menggunakan Model ADDIE”, intensif, vol. 3, no. 2, pp. 130-144, 2019. Tersedia : 
https://ojs.unpkediri.ac.id/index.php/intensif/article/view/12666. [Diakses : 21Agustus-2021]

[19] A. T. J. Harjanta dan B. A. Herlambang, "Rancang Bangun Game Edukasi Pemilihan Gubernur Jateng Berbasis Android Dengan Model ADDIE", JURNAL TRANSFORMATIKA, vol. 16, no. 1, pp. 91-97, 2018. Tersedia : https://journals.usm.ac.id/index.php/transformatika/article/view/894. [Diakses : 21Agustus-2021]

[20] H. Retnawati, "Perbandingan Akurasi Penggunaan Skala Likert dan Pilihan Ganda Untuk Mengukur Self-Regulated Learning”, JURNAL KEPENDIDIKAN, vol. 45, no. 2 , pp. 156-167, 2015. Tersedia https://journal.uny.ac.id/index.php/jk/article/view/7493. [Diakses : 3-September2021] 